\title{
Anthropology, social change and the reconstruction of South African society ${ }^{1}$
}

\author{
N.S. Jansen van Rensburg \\ Dept. of Social Anthropology \\ Potchefstroom University for CHE \\ POTCHEFSTROOM
}

\begin{abstract}
In this article it is argued that, since the abuse of anthropology in the colonial and apartheid eras, the responsive relationship between anthropology and society has been re-emphasised. In the reconstruction of South African society, therefore, anthropologists will not be allowed the luxury of evading their social responsibility. In their re-invention of anthropology as a humane science, and the reiteration of their commitment to accountability and relevance, these scientists ought to build their discipline upon the investigation of the major consequences of differential power and inequality. This could be helpful in creating new forms of co-existence in South Africa.

It is time that we lend "the sanction of science" to eliminating oppression, and one (but only one) way of doing this is to make clear and attack the role of anthropology in creating, preserving, and implementing idcologies of oppression (Farris, 1973:170).
\end{abstract}

\section{Introduction}

Will we in this decade of rapid social change, live to see anthropology used and abused to further or support social engineering, similar to that of the past? One may ask, based on the epistemology of writers such as Barrett, Scholte, reflexive anthropology in general, ${ }^{2}$ and lessons that can be learned from the history of anthropology, what direction the approach to and the practice of anthropology might take during this decade in South Africa. Whereas an optimist may view the history of the scientific knowledge of the discipline as cumulative, the reality may

1 A draft of this paper was presented at a Conference of the Association for Anthropology in Southern Africa, Scptember 1991, Rand Afrikaans University, Johannesburg. I am gratcful for comments from M. Elainc Botha and Arnold S. de Beer on the original draft.

2 De Jongh, 1991:100-106; Kotzć, 1990:40-62

Koers 59(1) 1994:3-18 
be closer to an oscillation between polar positions (Barrett, 1984), in which the mistakes of the past are often repeated.

The responsive relationship between anthropology and the society in which it evolves, has often and cogently been shown (cf. Asad, 1973; Scholte, 1981; Scholte, 1974; Barrett, 1984). Also, some future projections and anticipations regarding developments in South African anthropology ought to be evident, albeit vague and tentative. Therefore, I want to argue that social and political changes in South Africa will definitely have an influence on the future content and practice of anthropology in this country. The imminent changes that one can expect in the discipline, will also have a closer relationship with the views of radical or progressive academics, rather than with those of diametrically opposing views.

What then, should the commitment of most anthropologists in a future South Africa be? What issues or social problems will they view as important to grapple with in the reconstruction of South African society? Also, what were the most important mistakes made by anthropologists during the colonial and apartheid eras? In what way can the underlying dangers of the commitment to the reconstruction of South African society be evaded? In the process of the empowerment of some deprived categories in society, the task of anthropologists will be relatively easy, eg. when studying the position of women, children and the poor, but not so when 'studying up' 3 and doing research on a present or future political elite and bureaucracy. We already have a clear historical example in the apartheid era where a definite world view and commitment served as a dynamo for the reconstruction of South African society. Often those in political power retained the services of anthropologists as apologists, sustainers or architects of the system of apartheid. Commitment of anthropologists to social causes, in this case had its dire influence on the practice of anthropology in South Africa.

If the political commitment of certain anthropologists during the colonial era and more specifically the apartheid era is criticized, it is mainly because of their embroilment in the unequal power relations of these situations and the choice of a significant number of them in favour of the powerful.

My own approach is that there will always be an unequal distribution of power in all societies. Anthropologists should not only be clearly aware of the differential power relations in any society, they should also study these with the view to renewal and scholarship for justice-in-shalom (Wolterstorff, 1984:134). 


\section{Neutrality and positivism: a pair of dodo's?}

The grave implications for scientists viewing the theory and practice of science as politically neutral can not be overemphasized. ${ }^{4}$ Perhaps this can also be regarded as the main failures of eminent anthropologists such as Radcliffe-Brown and his followers who had a telling influence on the discipline in South Africa. RadcliffeBrown in his scientistic approach, viewed liberal knowledge as: "... of value itself, for and in itself" (Cape Times, 16 March 1923, cited by Gordon, 1990:24). This view has already been criticized by Gluckman in the sixties when, with regard to Malinowski's model and its application to South Africa, he expressed the view that according to some: "Knowledge alone cannot make a moral policy; it can as easily serve an immoral one" (Gluckman, 1963:210-11, cited by Gordon, 1990:33). The gravity of the results of so-called politically neutral science becomes clear when one realizes that "... anthropology has been politicised [precisely] in the sense that its implicit political nature and explicit political promise have been either obfuscated or banned from 'scientific' discussion" (Scholte, 1981:151).

The final death throes of positivism seem evident in scientists of this decade accepting that "Mathematical ideas, like any other ideas, are humanly constructed. They have cultural history" (Bishop, 1990:52). During the last three centuries of the cultural history of mathematics, this discipline developed as part of Western European culture, which played such a powerful role in achieving the goals of imperialism. The three major mediating agents in the process of cultural invasion in colonised countries by Western mathematics seem to have been trade, administration and education (Bishop, 1990:53-59). Surely, if this is true of mathematical 'objective facts', how can the 'science of man' in some instances still plead political neutrality? In this discussion the tradition of a Christian commitment aiso regarding the theory and practice of science, is accepted as a guideline and as control. This of course, also implies a debate on possible "... revisions induced in our actual commitment, and in our views as to what constitutes authentic commitment, by scientific developments" (Wolterstorff, 1976:72-80; 88-93).

4 The sub-discipline, namely structural-functionalism, developing from the high value placed on rigorous ficldwork, judged their effort to be an objective recording of reality and that the scientific laws discovered in the process, "... would by definition be immutable, true for all times and places, and independent of the assumptions and prejudices of the lay public" (Sharp, 1988:3 et seq.). Although in this article, specific attention will be paid to the necessity of political engagement, the viewpoint that involvement by academics is multifaceted and indeed, that science in general is not neutral, is accepted (Botha, 1980:45-46). 


\section{Responsive relationships - sociology of knowledge and knowledge of society}

The nature of 'complicity' of anthropologists in 'political' issues must, according to Farris (1973:154), be viewed from a fundamental perspective. That some anthropologists may have been politically liberal, or even left-leaning, is simply irrelevant. These individuals may even have attempted to aid local oppressed peoples, but:

... without an analysis of the generation of such oppression, very little could come of their efforts. In fact, they probably acted to inhibit oppressed peoples from overtly attacking the colonial regime. It is of course wrong to attribute insidious motives to the vast majority of anthropologists, but functionalism had its functions quite apart from any conscious intentions of its proponents. If our science doesn't change with our politics, we can hardly be of much intellectual help in struggles against various manifestations of imperialism. Not only must the content and application of our science change, but also our theory and methodology. 5

These somewhat generalised truths have also been studied in more detail to indicate the complicated and nuanced situation on ground level. James (1973) for instance, discusses what she calls radicalism of a moral sort which in the academic field has led academics to defend the moral rights of peoples living under colonial administration; thumb their noses at the sacred civilising mission; refuse to side unambiguously with the colonial attitude; and for Malinowski himself, there were even signs of "a deepening personal radical commitment" (James, 1973:66;41-69; cf. also Feuchtwang, 1973:96; Burton, 1992). On the other hand, the importance of the "unequal power encounter" between the West and the Third World must clearly have had a direct bearing on the kind of understanding that would confirm the powerful in their world as against the slight possibility of the production of "radically subversive forms of understanding" by anthropologists (Asad, 1973:16)

Two decades ago one could still say that the ignoring or insufficient account taken of the colonial situation 6 and the issue of value-commitments and objectivity

5 Barrett (1984:xi-xii) in his moral statement refers to the importance of the recognition of the consequence of differential power and the larger societal framework in which the deprived are caught.

6 Diamond (1980:2) views anthropology as "... an aspect of the intellectual history of Western civilization - at its worst the mortician of that civilization - laying out and presenting victimized cultures to public scrutiny, after the explorer, trader, soldicr, missionary and administrator had done their work". 
were serious impediments in anthropology (Forster, 1973:25). At this stage of the history of science, however, few will counter the view of the responsive and even direct interaction between anthropology and the society in which it is operating as part of societal activities. ${ }^{7}$

South African anthropology's association with social and political circumstances has often been indicated (cf. Mafeje, 1971; Thornton, 1988; Boonzaier, 1988:6567). The important influence of social and political changes (also in Africa) on the object, the ideological support and the organisational base of social anthropology, especially since the Second World War, have been discussed extensively in research literature. Most important was the realisation among some anthropologists that "... anthropology does not merely apprehend the world in which it is located, but that the world also determines how anthropology will apprehend it" (Asad, 1973:12). In these discussions, the colonial circumstances regarding South Africa, the apartheid era and the relationship of these with anthropology, have been the main contenders for attention in the literature on the subject. The more recent and changing South African political and social situation, however, has not been sufficiently analysed with a view to speculate on the possible future development of South African anthropology. In this discussion attention will also be paid to some possible future developments and what role anthropologists could play in becoming responsible stewards in their study of South African society.

\section{The South African situation}

\subsection{Colonialism and apartheid}

The colonial power structure made possible the intimacy on which anthropological fieldwork was based, but also ensured that the intimacy was one-sided. Sometimes anthropology contributed indirectly towards maintaining the structure of power represented by the colonial system. In some cases this was critical for the small discipline that offered knowledge and received patronage. One can also accept that the structure of power affected the theoretical choice and treatment of what anthropology objectified (Asad, 1973: 17-19; cf. also Skalník, 1988:72-74). Of more serious implication was that the colonial system as such, within which the social objects studied were located, was not analysed by anthropology, perhaps because the anthropological expertise was malformed (Asad, 1973:18).

7 Although the thesis that our theories change in response to changes in society is a powerful one, the conventional sociology-of-knowledge approach cannot cope with the highly "repetitive, oscillating, pendulous nature" of the history of anthropology (cf. Barrett, 1984:77-79) 
Since the initial settling of people of European descent in Southern Africa, and the subsequent centuries of gradual but sure build-up of white power, missionaries, officials and travellers, in varying degrees have offered their contributions to the 'anthropological knowledge' of the sub-continent. The nature of the information and its dialectical relationship with the powerful position of white society has been indicated (Thornton, 1988). The conceptual framework created in this period included the Romantic idea of culture as the organic product of a people or nation - an idea which has had an enduring influence on the vocabulary of South Africa as seen in the coining of distinct terms such as Bantu, Hottentot and Bushman; the re-introduction of ancient oppositional terms such as civilised and un-civilised; the use of the Tylorian culture concept as isolationist (?) "wholes" within a "society" (Thomton, 1988:20-23). The idea of cultures as wholes, belonging to specific nations - and the isolation of groups - clearly formed an excellent basis for the legitimation of political systems in the colonial and apartheid eras.

The Union of South Africa was constituted and the years immediately following led to the culmination and consolidation of white power and economic control. Seen from the viewpoint of those in power, and with respect to the universal tendency regarding the use (or abuse) of science as indicated above, the creation of a science to support the status quo, was to be expected.

Two strands can be identified regarding the debate on this issue, which in recent years has attracted new interest. The accusation has in some instances been made regarding the adverse effect and role of functionalist anthropology in the South African society and specifically its support of the colonial system (Joseph et al., 1990:16; Sharp, 1988:5-10). Criticism has also been levelled against structural functionalism by authors such as Mafeje (1971) in his discussion on the 'creation' of the word tribe in some cases and the entities in others (see also Ranger, 1983).

These generalized views have recently been strongly and effectively criticized by Gordon. He indicated, for instance, that the approach of Radcliffe-Brown could not have been the basis for the segregationist views, which developed in South Africa in the early years of this century. Furthermore he indicated that the Afrikaans-speaking anthropologists (volkekundiges) who expounded clear apartheid ideas, quoted Malinowski's theory of the meeting of different cultures in South Africa, and not the ideas of Radcliffe-Brown which can be typified as a social 
structure and "single-systems approach" (Gordon, 1990:30-31). ${ }^{8}$ This does not address all the criticism indicated, although it absolves some social anthropologists from the direct responsibility they might have had regarding their possible support for segregationist policies.

As a more focused argument, detailed material have been published to evince the direct and profuse contribution which many prominent Afrikaans-speaking anthropologists made to the creation and support of the apartheid idea and system (Sharp, 1981). This phenomenon can be connected to the political power change in South Africa in 1948. Especially since the Verwoerdian era, the National Party endeavoured to expound the grand idea of separate development. They introduced the idea of separate development to all spheres of life, including academic life. A number of Afrikaans-speaking anthropologists played a significant role in the legitimation and production of the apartheid social order (see Gordon, 1988; Sharp, 1981; West, 1979). Especially Gordon (1988) gives a detailed discussion on the ideological, organizational and social network existing between almost all prominent Afrikaans anthropologists of the early years, the state and civil service and important Afrikaner organizations.

\subsection{Cracks in the facade of apartheid and the advent of radical anthropology}

Despite its relative isolation, South African anthropology did not escape world trends. Barrett (1984:77-78) argues that, whereas the era of imperial expansion was consistent with evolutionism, structural functionalism and its anti-historical emphasis suited colonialism. With the end of the Second World War and the emergence of newly independent nations the conditions were ripe for a new kind of theory, one that emphasized change in the form of neo-evolutionism, structuralism, and a renewed emphasis on dialectics and Marx (cf. also Marfleet, 1973).

Caught in the midst of a social struggle since the sixties, South Africa went into the period of the Soweto uprisings in the late seventies. This not only tolled the first clear bell for the demise of white power, but also brought to the fore young 'radicals' practising anthropology and history. Although the protagonists of 'radical' anthropology were initially small in numbers, a powerful reassessment of the fruitfulness of the mainly structural-functionalist approach in anthropology

8 Apart from this, Gordon (1990:34) argucs that works such as that of Asad (1973) mistakenly accuse anthropologists of a dogmatic homogencity and do not account for the internal critique which was very much alive in the heyday of 'scientific' colonialism. Cf. also Kuper, 1986. 
Anthropology, social change and the reconstruction of South African society

was pursued. This reassessment had a fundamental nature and was mainly influenced by a form of Marxism (Sharp, 1981; Sharp, 1985; cf. Kuper, 1986)

\section{Reconstruction and the role of anthropology in a future South Africa}

Dramatic political and social changes in South Africa have been activated. During the creation of an open and democratic society, social forces and needs might have a positive influence on the development of anthropology. Because of the debilitating effects of South African social and political history, especially the skewing of privileges and the resulting over-expectations of many people, all these social changes will not necessarily be painless or welcome, also for the practitioners of anthropology. One of the most important potential gains from the history of South African anthropology will be our ability to repeat only some mistakes (for that is human nature), but not all (for that is asinine nature) of the immediate past.

Based on the premise that the social and political changes in South Africa are shaped by encompassing forces, the effects and responsibilities of change cannot be escaped, also in the academic sphere. Anthropologists should play a positive and constructive role in this rapidly changing society. What approaches can one expect regarding the interaction between anthropologists and society? Will these approaches keep us from repeating the mistakes of the immediate past? The first steps in the direction of becoming constructively involved without repeating the mistakes of the past will be to become truly reflexive in practising our discipline.

\section{Views on science and social commitment}

\subsection{Introspection, context and reflexivity}

Scholte (1981:149), following recent developments in the sociology of knowledge in his work, emphasizes the importance of the critical examination of the history and structure of the "... Lebenswelt that is presupposed by any and all forms of 'anthropological praxis' in the sense that 'the questioner', the question, and the questioned are one". 9 Also, one of the solutions to the problems of anthropology is its recognition of its mediated status and the important task of inquiring into the anthropological grounds that generate, transform or discontinue these culturally acquired and socially established conceptions of universality and truth (Scholte, 1981:149;156). This means that we should be more willing to apply our own

9 In reformational philosophy of science, this problem is not new (sce Marshall, et al., 1989). 
methods of studying cultural phenomena to ourselves (Harris, 1968:290) and our science, because in South Africa, even the view of science as the ideal of the orderly process of reason can be shown to be a mediated cultural activity, which is often "... hierarchical, authoritarian, sexist, and, in their assumption of the superiority of Western modes of thought, racist ..." (Rose \& Rose, 1974:154, cited by Scholte, 1981:165).10

In keeping with the approach of introspection as an epistemological principle, some critical anthropologists also seek to transcend the naive dualism of subject and object (cf. Pandian, 1985:6) and to inquire into the communicative and constitutive relation between self and other as the absolute foundation of anthropological praxis. ${ }^{11}$ This does not mean self-denial, but self-understanding, an understanding of the inter-subjective basis of anthropological inquiry, not anthropology as "... a privileged way of maintaining distance in the name of science, not only from the people one 'studied', but from one's own cultural predicament, from oneself', that becomes essential for this discipline (Diamond, 1974, cited by Scholte, 1981:160-161). The above view is the opposite of the practice of scientific colonialism, whereby the centre of gravity for the acquisition of knowledge about a people is located elsewhere. Scientific colonialism also ties in with the influence of Eurocentrism in anthropology that still needs to be researched on the local level. 12

\subsection{Humanity, a humane anthropology and human benefit}

It seems as if colonialism, apartheid and its handmaiden, anthropology, mostly emphasized structures and ideas and did little for simple humans. Anthropology became entrapped in power struggles in a broad sense, to the detriment of those

10 See also Pandian's (1985) exposition of the construction of self in Judeo-Christian tradition, and the subsequent construction of the savage other, the black other and the ethnographic other in Western tradition. Pandian also argues that, whereas pcople everywhere make the distinction between us and the other "In the anthropological tradition, the other is in us" (Pandian, 1985:125).

11 According to Hountondji (1976, cited by Augc, 1982:84) it would be wrong to create a body of knowledge in which cverything once again happens outside the African himsclf, and something such as for instance 'Bantu philosophy' "... serves mercly as a pretext for a discussion between learned Europcans. The Black is thercfore still quite the opposite of a spokesman: he is that about which one spcaks, a face without a voice that one trics, with the help of one's colleagues, to decipher. He is an object to be defined and not a subject of a possible discourse".

12 According to Joseph et al. (1990:17), an important influence in colonial anthropology came from the romantic approach, which was and is Eurocentric in that it uses or creates images of other peoples in terms of the cognitive needs and interests of Europeans. 
Anthropology; social change and the reconsmuction of South African society.

without power and it seriously damaged its own image. In many cases it simply made the most convenient choices for the furtherance of "scientific" self interest

Some part of anthropologists' dissatisfaction with the state of their discipline and its performance lies in the irony that the 'study of man' does not answer to the needs of men and women. This situation ought to be changed so that anthropologists should "... ask of anthropology' what they ask of themselves - responsiveness, critical awareness, ethical concern, human relevance, a clear connection between what is to be done and the interests of mankind" (Hymes, 1974:7)

\subsection{Accountable to and relevant for whom?}

In the discourse regarding responsiveness, the issue of accountability often surfaces. In certain circles in South Africa, accountability has, among other things, been seen as associated with the mass democratic movement and the necessary contribution to the struggle, by trying to develop a range of skills, knowledge, and involvements. This has been qualified somewhat by certain authors because:

... the individual researcher can still limit his/her involvement to traditional 'academic' work. but must nonetheless ensure that $\mathrm{s} / \mathrm{he}$ remains connected to, informed by, and accountable to the other relevant interest groups. and exercises rigorous self-critique in terms of his/her own research practice (URWGC, 1990:46, 47)

The same authors also refer to the importance of defining these demands in the current context and wam against using academic skills solely for activist or immediatist activities which could end in a wasteful utilization of resources (URWGC, 1990:52).

Because of the demands of our time and the intensity of the political struggle, oversimplification of these issues can be seen when "... academics contribute to community struggle by producing knowledge via their teaching and research work which is emancipatory, and which serves the liberation movement in an intellectual and ideological manner" (URWGC, 1990:53).13 Of course, certain political choices have already been made in these cases but, will these choices

13 In their discussion on relevance and excellence in the academic ficld some of these authors do have nuanced and well argued vicws. but these views are not as clear regarding the implications of a dircet political commitment (Bundy at al, 1990:56-63). Sce also Wolterstorff s (1984:117-135) excellent vicwpoint on the "justification for theorizing" and the necessity to engage in "praxis-orientated theory" because "repcatedly the knowledge we need for our noncognitive goals proves not to have cmerged from purc thcory" (Wolterstorff, 1984:132-133) 
N.S. Jansen van Renshurg

necessarily change in response to contextual changes and will they change contiguously in a way that will benefit the broad society in future?

Arising from the discussion on the impossibility of a politically value-free science, is the danger of anthropology becoming irrelevant. The close connection between both the colonial systems and the apartheid governments in South Africa and at least some individual anthropologists has been indicated. This is clearly an indication of the 'relevance' (utility) of our discipline. The question that therefore needs to be asked is for whom must anthropology be relevant? Those who choose to focus on fundamental theoretical aims are sometimes too easily consigned to the Ivory Tower. Over-emphasis on relevance not only implies shortterm aims, it also tends to be relative to certain situations and interests. Clearly the most recent developments in South Africa notwithstanding, it would be absurd to argue that political commitment be left to left-wing ideology only (cf. Forster, 1973:26-31). We all need to become involved and committed. For instance, the Association for Anthropology in Southern Africa's Ethical Guidelines (AASA, $1987: 2$ (i) \& (ii)) include the call to members to "... call attention to inequalities, cases of blatant injustice, violence and intrusion upon individual freedom ..." and also declared themselves to be opposed to the system of apartheid. These views should, of course, be seen within the context of the South African situation at the time, but, if taken seriously, and acted upon with integrity, should be extended to the post-apartheid era.

\subsection{Race and gender}

Many social problems in South Africa have their origin in differential power and social inequality. These problems include crucial issues such as welfare and poverty, sexism and racism "profiled against a common background of bureaucracy and elites" (Barrett, 1984:222). It is both interesting and important for South African anthropologists that Barrett (1984:223), as a result of his research in this area, also mentions the necessity for the further study of racism. He finds that the social anthropology of racism can be summed up in a few words "... it has been a dismal failure". 14

In many spheres of South African academic life, and also that of anthropological practice, blacks and women are only marginally involved in the production and shaping of knowledge. Especially in the area of research there is a definite white male monopoly. Although the practical redress of this situation is an important

14 Sec also the argument of Fyfe (1992:19) that "A white skin [in Africa] conferred authority and commanded deference from those without it" and how this has becn ignored by some historians 
Anthropology, social change and the reconstruction of South African society

and complex issue, the main academic issue to consider here, is that this will be a crucial factor when looking into the typical colonialist situation in which anthropology has become entrapped. The important demands of accountability and responsiveness to the broad population necessitate taking the history of the discipline into account. However, even the urgency of redressing and researching this problem, should not be used to subordinate intellectual autonomy to state policies or to narrow communal needs in future (Evans, 1990).

\section{Conclusions}

Despite the abuse of anthropology by ourselves and our predecessors, a commitment by anthropologists is not only necessary but inevitable. Findings in the studies cited above, indicate the effect of so-called neutrality. In a country ravaged by centuries of human manipulation by the powerful and decades of complicity, 'neutrality' and powerlessness of anthropologists, we cannot afford the luxury of pleading scientific neutrality in our research, which in this country often proved to be support for the status quo.

I believe that Barrett $(1984: 211-212 ; 220-237)$ refers to vital issues that we need to address, the most crucial of which is that "the discipline must be built around the investigation of the major consequences of differential power and inequality [as also used by the scientific establishment] with the goal of changing and improving society" (cf. also Wolf, 1990:592). ${ }^{15}$

Anthropologists will definitely have to do some serious restructuring (or even reinvention) of their discipline to be regarded as legitimate by the broad South African society. Our discipline will have to disengage itself from the chains of its past, be it as "the child of Western imperialism" (Kathleen Gough, quoted by Marfleet, 1973:276), colonialism or apartheid. However, can we, serving the interests of the broad society, be seen to simply accept any specific (present or future) political dispensation? Here one should also consider Barrett's (1984:234237 ) illuminating argument that field-work is a form of subversive activity. ${ }^{16}$ In

15 Hymes (1974:52) has an even more radical (but nuanced ethical) view, with far reaching political and moral implications when he hopes to see "... the consensual ethos of anthropology move from a liberal humanism, defending the powerless, to a socialist humanism, confronting the powerful and secking to transform the structure of power".

16 Barrett remarks: "We study to learn, and possibly to help, but in the course of doing so we expose and implicitly criticize. We reveal the inner workings of a social system after pecling off the protective layer of rationalizations that conceals it." The implications of this argument are far-reaching. Especially in the case where research really becomes subversive because we leam more than is acceptable to those with vested interests and power positions, we must not in future allow a concern for professional ethics to bccomc an cuphemism for cthical neutrality (Barrett, 1984:236-237). These issucs become even 
using his/her powerful tools of analysis, the South African Christian anthropologist should always consider the possible direction of his/her inquiries and keep in mind that overall renewal is needed, that liberation although important, is not adequate. Our goal should be shalom (peace) with God, ourselves and our fellows (Wolterstorff, 1984).

Anthropology in South Africa cannot be value-free, and indeed requires a valuecommitment, for, by virtue of its subject matter, anthropology is a political and ethical discipline and not merely an empirical speciality (Hymes, 1974:48). Anthropology requires a conscious acceptance of the socio-political and intellectual dangers and possibilities of value-commitment (Scholte, 1981:174-175).

In making our political choices we should be aware of the dangers of intimacy with and patronage from sections of our community. The convenience of too close a relationship with any interest group, especially those in positions of power, can be very tempting. This applies equally to our theoretical choices, the practice of our discipline, and the application of our knowledge. Because of the too close relationship of anthropologists with sections of society in the past, our co-workers illuminated our repeated inability to analyse our unequal world and the consequences of our not being able to challenge it. An intimate relationship with specific interest groups does not only endanger scientific autonomy and the freedom to make moral and political choices. At this juncture in South African history it can also be crucial in the construction, furtherance and legitimation of an unjust social system, present or future.

A truly acceptable and humane "anthropology of experience" (Berreman, 1974:92) has still to be created in South Africa. To be of real value to the broad community, the concerted effort of the majority of well-meaning anthropologists will be required. Perhaps the most important step will be to learn from our past and not to be caught up in social or political power struggles in a facile way. Especially at this stage of social transformation within South African society, anthropologists must be of some help in the emergence of new forms of co-existence, thereby enabling people to be in more rational control of their social environment, because they comprehend social reality more explicitly, and also by seeking to help members of society to participate in the work of anthropology (Hymes, 1974:54). For a Christian this humanizing of the world and even the

more important in a discipline gradually showing more signs of "studying up" (cf. Nader. 1974). Ablon (1982:39), cited by Barrett (1984:237), has a practical view on this issuc when he says: "We and others may work till doomsday with the impoverished and politically impotent but accomplish very little for general economic or social reform until middlc and upper class populations are understood and moved to social and political action. Therefore, it can be argued that the mandate to work with these populations is our calling at this time." 
Anthropology, social change and the reconstruction of South African society

working for human benefit is acceptable, but attention must also be given to the theme of fall and renewal to reorientate us with regard to our responsibilities. This approach will lead to our cultural fulfilment as academics but also commit us to the struggle for breaking the chains of deprivation and oppression (Wolterstorff, 1984: 141-143).

\section{References}

AASA. 1987. Association for Anthropology in Southern Africa; Ethical Guidelines, Section 2(i)\&(ii).

ABLON, J. 1982. Field Method in Working with Middle Class Americans. (In Cole, J. ed Anthropology for the Eighties. New York : Free Press.)

AUGÉ, M. 1982. The Anthropological Circle: Symbol, Function, History. Cambridge : Cambridge University Press.

ASAD, T. ed. 1973. Anthropology \& the Colonial Encounter. London : Ithaca.

BERREMAN, G.D. 1974. "Bringing it All Back Home": Malaise in Anthropology. (In Hymes, D. ed. Reinventing Anthropology. New York: Vintage. p. 83-98.)

BARRETT, S.R. 1984. The Rebirth of Anthropological Theory. Toronto : Univ. of Toronto.

BOONZAIER, E. 1988. 'Race' and the Race Paradigm. (In Boonzaier, E. \& Sharp, J. eds. South African Keywords: the Uses and Abuses of Political Concepts in South Africa Cape Town : David Philip. p. 59-67.)

BOTHA, M. Elaine. 1980. School in Society. (In The Responsibility of Christian Institutions of Higher Education to Justice in the International Economic Order. Proceedings of the Second International Conference of Reformed Institutions for Christian Higher Education. Calvin College, Grand Rapids, Mich. 13-19 August, 1978. Grand Rapids : Board of Publications of the Christian Reformed Church. p. 43-66.)

BISHOP, A.J. 1990. Western Mathematics: the Secret Weapon of Cultural Imperialism. Race \& Class, 32(2):51-65, Oct.-Dec.

BUNDY, C. et al. 1990. Theory is the Most Practical Form of Knowledge: Academic Excellence and the Ideal of a People's University. UWCADE Forum, 1(1):56-63.

BURTON, J.W. 1992. Representing Africa: Colonial Anthropology Revisited. Journal of Asian and African Studies, 27 (3-4):181-201.

DIAMOND, S. 1980. Introduction. (In Diamond, S. ed. Anthropology: Ancestors and Heirs. The Hague : Mouton. p. 1-16.)

DE JONGH, M. 1991. Refleksiewe antropologie; 'n Betoog vir wetenskaplike subjektiwiteit. South African Journal of Ethnology, 14(4):100-106

EVANS, I. 1990. The Racial Question and Intellectual Production in South Africa. UWCADE Forum, 1(1):7-27.

FARRIS, J.C. 1973. Pax Britannica and the Sudan: S.F Nadel. (In Asad, T. ed. Anthropology \& the Colonial Encounter. London : Ithaca. p. 153-170.)

FEUCHTWANG, S. 1973. The Colonial Formation of British Social Anthropology. (In Asad, T. ed. Anthropology \& the Colonial Encounter. London : Ithaca. p. 71-100.)

FORSTER, P. 1973. Empiricism and Imperialism: a Review of the New Left Critique of Social Anthropology. (In Asad, T. ed. Anthropology \& the Colonial Encounter. London : Ithaca. p. 23-38.)

FYFE, C. 1992. Race, Empire and the Historians. Race \& Class, 33(4): 15-30.

GORDON, R. 1988. Apartheid's Anthropologists: the Genealogy of Afrikaner Anthropology. American Ethnologist, 15(3):535-553.

GORDON, R. 1990. Early Anthropology in South Africa. African Siudies, (1):15-48. 
HARRIS, M 1968. The Rise of Anthropological Theory. New York : Crowell.

HOUNTONDJI, P. 1976. Sur la 'philosophie' africaine Paris

HYMES, D. 1974. The Use of Anthropology: Critical, Political, Personal. (In Hymes, D ed. Reinventing Anthropology. New York: Vintage. p. 3-79.)

JAMES, W. 1973. The Anthropologist as Reluctant Imperialist. (In Asad, T ed Anthropology \& the Colonial Encounter. London: Ithaca. p. 41-69.)

JOSEPH, G.G., REDDY, V. \& SEARLE-CHATTERJEE, M. 1990. Eurocentrism in the Social Sciences. Race \& Class, 31(4):1-26.

KOTZE, J.C. 1990. Science as Effective Social Communication: Subjectivity and a "Possible World of Common-Sense Reality". Communicare, 9(2):40-62

KUPER, A. 1986. The Anthropologist's Vocation in South Africa. African Studies, 45(1):115

MAFEJE, A. 1971. The Ideology of Tribalism. Journal of Modern African Studies, 9(2): 253-261

MARFLEET, P. 1973. Bibliographical Notes on the Debate. (In Asad, T. ed. Anthropology $\&$ the Colonial Encounter. London: Ithaca. p. 273-281.)

MARSHALL, P.A., GRIFFIOEN, S., MOUW, R.J. eds. 1989. Stained Glass: World Views and Social Science. Lanham : Univ. Press America

NADER, L. 1974. Up the Anthropologist - Perspectives Gained from Studying up. (In Hymes, D. ed. Reinventing Anthropology. Vintage : New York. p. 284-311.)

PANDIAN, J. 1985. Anthropology and the Western Tradition; Toward an Authentic Anthropology. Prospect Heights : Waveland

RANGER, T. 1983. The Invention of Tradition in Colonial Africa. (In Hobsbawm, E. \& Ranger, T. eds. The Invention of Tradition. Cambridge : Cambridge University Press. p. 64-76.)

SCHOLTE, B. 1974. Toward a Reflexive and Critical Anthropology. (In Hymes, D. ed. Reinventing Anthropology. Vintage : New York. p. 430-457.)

SCHOLTE, B. 1981. Critical Anthropology Since its Reinvention. (In Kahn, J.S. \& Llobera, J.R. eds. The Anthropology of Pre-capitalist Societies. London : Macmillan. p. 148184.)

SHARP, J. 1981. The Roots and Development of Volkekunde in South Africa. Journal of Southern African Studies, 8(1):16-36.

SHARP, J. 1985. Unit of Study, Context and Culture: Towards an Historical Anthropology African Studies, 44(1):65-85.

SHARP, J. 1988. Introduction. (In Boonzaier, E. \& Sharp, J. eds. South African Keywords the Uses and Abuses of Political Concepts in South Africa. Cape Town : David Philip p. 1-16.)

SKALNIK, P. 1988. Tribe as Colonial Category. (In Boonzaier, E. \& Sharp, J. eds. South African Keywords: the Uses and Abuses of Political Concepts in South Africa. Cape Town : David Philip. p. 68-78.)

THORNTON, R. 1988. Culture: a Contemporary Definition. (In Boonzaier, E. \& Sharp, J eds. South African Keywords: the Uses and Abuses of Political Concepts in South Africa. Cape Town : David Philip. p. 17-28)

URWGC

see

UWCADE RESEARCH WORKING GROUP COLLECTIVE

UWCADE RESEARCH WORKING GROUP COLLECTIVE. 1990. Unraveling the Contradictions Between Teaching, Research Output and Political Practice at UWC Today. UWCADE Forum, 1(1):42-55 
Anthropology, social change and the reconstruction of South African society

WEST, ME. 1979. Social Anthropology in a Divided Society. (Inaugural Lecture delivered at the University of Cape Town, 16th. May 1997; New Series no. 57). Cape Town University of Cape Town

WOLF, E.R. 1990. Distinguished Lecture: Facing Power - Old Insights, New Questions American Anthropologist, 92:586-596.

WOLTERSTORFF, N. 1976. Creation Regained; Biblical Basics for a Reformational Worldview. Grand Rapids : Eerdmans.

WOLTERSTORFF, N. 1984. Reason Within the Bounds of Religion. Grand Rapids : Eerdmans 